\title{
VARIASI TUGAS DAN AKTIVITAS PEMBELAJARAN DI SEKOLAH DASAR PADA MASA PANDEMI CORONA
}

\author{
Lathifah Nurul Hidayah $^{1}$, Laili Etika Rahmawati ${ }^{2}$, Lupita Sari Pitra Wardani ${ }^{3}$ \\ 1,2,3Pascasarjana Pendidikan Bahasa Indonesia, Universitas Muhammadiyah Surakarta \\ email': $\underline{\text { s200190003@student.ums.ac.id }}$
}

\begin{abstract}
Abstrak: This research aims (1) to identify task variations in elementary school during the corona pandemic; and (2) to identify learning activities in elementary school during the corona pandemic. This research approach is descriptive qualitative. The data of this research are the the forms of task and learning activities during the corona pandemic. The data source comes from elementary school teachers in the Boyolali area. Data collection in this research uses a questionnaire in the form of Google Forms. The data analysis in this research uses an interactive method. The results showed (1) the task variations in elementary school during the corona pandemic in the form of portfolios, practice, and exercise. Applications or media that are mostly used by elementary school teachers in giving assignments during the corona pandemic namely Whatsapp; and (2) the learning activities in elementary school during the corona pandemic is the provision of instructional videos from YouTube, questions and answers discussion through Whatsapp, and working on exercises.
\end{abstract}

Keywords: task variations, learning activities, corona, online learning

Abstrak: Penelitian ini bertujuan (1) mengidentifikasi variasi tugas di Sekolah Dasar pada masa pandemi corona; dan (2) mengidentifikasi aktivitas pembelajaran di Sekolah Dasar pada masa pandemi corona. Pendekatan penelitian ini adalah deskriptif kualitatif. Data penelitian ini adalah bentuk-bentuk tugas dan aktivitas pembelajaran pada masa pandemi corona. Sumber data berasal dari guru-guru SD di wilayah Boyolali. Pengumpulan data pada penelitian ini menggunakan kuesioner dalam bentuk Google Forms. Analisis data pada penelitian ini menggunakan metode interaktif. Hasil penelitian menunjukkan (1) variasi tugas di Sekolah Dasar pada masa pandemi corona berupa portofolio, praktik, dan soal latihan. Adapun aplikasi atau media yang banyak digunakan guru SD dalam memberikan tugas pada masa pandemi corona yaitu Whatsapp; dan (2) aktivitas pembelajaran di Sekolah Dasar pada masa pandemi corona ialah pemberian video pembelajaran dari Youtube, diskusi tanya jawab melalui aplikasi Whatsapp, dan mengerjakan soal latihan.

Kata kunci: variasi tugas, aktivitas pembelajaran, corona, pembelajaran daring

\section{PENDAHULUAN}

Berkembangnya wabah corona di Indonesia ternyata tidak hanya berdampak pada sektor ekonomi saja yakni merosotnya perekonomian di Indonesia, jatuhnya nilai tukar rupiah, dan harga barang naik termasuk alat-alat kesehatan (Pratiwi, 2020). Akan tetapi, wabah corona juga berdampak pada sektor pendidikan di Indonesia. Sudah lebih dari satu bulan lamanya semenjak kemunculan virus corona di Indonesia, pelajar di Indonesia melaksanakan pembelajaran dari rumah dengan sistem daring. Hal tersebut tidak lain mengikuti Surat Edaran dari Menteri Pendidikan dan Kebudayaan Nomor: 36962/MPK.A/HK/2020 tertanggal 17 Maret 2020 tentang Pembelajaran secara Daring dan Bekerja dari Rumah dalam rangka Pencegahan Penyebaran Corona Virus Disease (COVID-19). Kebijakan terkait dengan pembelajaran secara daring tersebut 
diterapkan oleh Menteri Pendidikan sematamata untuk memutus mata rantai penyebarang virus corona di lingkungan sekolah.

Adapun poin-poin yang perlu digarisbawahi yaitu belajar dari rumah melalui pembelajaran daring dilaksanakan untuk memberikan pengalaman belajar yang bermakna bagi siswa, tanpa harus terbebani dengan tuntutan capaian kurikulum yang harus tuntas agar dapat naik kelas atau lulus; belajar dari rumah dapat difokuskan pada pendidikan kecakapan hidup; aktivitas dan tugas pembelajaran selama belajar dari rumah dapat bervariasi disesuaikan dengan minat dan kondisi siswa itu sendiri; produk atau hasil belajar dari rumah diberi umpan balik yang bersifat kualitatif dan berguna dari guru. Pembelajaran daring itu sendiri bertujuan untuk memenuhi standar pendidikan dengan pemanfaatan Teknologi Informasi dengan menggunakan perangkat komputer atau gadget yang saling terhubung antara siswa dan guru atau antara mahasiswa dengan dosen sehingga proses belajar mengajar tetap bisa dilaksanakan dengan baik (Pakpahan \& Fitriani, 2020).

Bagi mahasiswa di Perguruan Tinggi, pembelajaran daring mungkin sudah hal yang lumrah dilakukan dalam kegiatan pembelajaran. Namun, bagi kalangan pelajar di Indonesia baik dari tingkat Sekolah Dasar, Sekolah Menengah Pertama, dan Sekolah Menegah Atas, pembelajaran daring mungkin dianggap hal baru di masa pandemi corona ini. Pembelajaran berbasis online dengan menggunakan berbagai macam aplikasi penunjang pembelajaran yang memungkinkan siswanya untuk selalu aktif di setiap kegiatan pembelajaran dari rumah. Proses pembelajarannya pun juga beda dengan pembelajaran yang dilaksanakan di sekolahan.

Selain dianggap baru bagi para pelajar di Indonesia, pembelajaran dengan sistem daring mungkin juga merupakan hal yang baru bagi kebanyakan para guru. Proses belajar mengajar yang biasanya dilakukan dengan cara tatap muka di dalam ruang kelas, kini berubah dilaksanakan dari rumah masing-masing siswa. Pembelajaran daring bukan sekedar memindahkan materi melalui media internet, buka pula sekedar tugas dan soal-soal yang dikirimkan melalui media sosial. Pembelajaran daring harus direncanakan, dilaksanakan, serta dievaluasi sama halnya dengan pembelajaran di dalam kelas (Syarifudin, 2020). Guru juga dituntut untuk aktif melaksanakan proses belajar mengajar dari rumah dan melakukan penilaian dari rumah. Tugas merupakan bentuk latihan yang diberikan guru kepada siswa agar siswa benar-benar memahami materi suatu pelajaran. Tugas juga merupakan salah satu bentuk penilaian bagi guru untuk melihat bagaimana pemahaman siswa tentang materi pelajaran yang telah dipelajari (Endriani \& Syukur, 2015). Hal ini dapat disimpulkan bahwa salah satu cara yang dilakukan oleh guru dalam hal proses belajar mengajar dan penilaian selama siswa belajar dari rumah yakni pemberian tugas kepada para siswanya.

Setiap guru memiliki cara tersendiri dalam memberikan tugas pada siswanya. Tak terkecuali tugas yang diberikan pada siswasiswi Sekolah Dasar. Jenis-jenis tugasnya yang diberikan guru antara siswa Sekolah Dasar dengan Sekolah Menengah Atas tentu juga berbeda. Tugas-tugas yang diberikan kepada anak Sekolah Dasar tentu lebih banyak menekankan pada pengalaman belajar yang bermakna bagi siswa. Belajar di rumah dapat difokuskan pada pendidikan kecakapan hidup antara lain mengenai pandemi Covid-19 (Dewi, 2020). Adapun hasil dari penelitian terdahulu yang dilakukan oleh (Dewi, 2020) yaitu pemberian tautan yang berisi materi pelajaran sekaligus tugas serta batas waktu pengerkaan melalui google doc dinilai lebih mudah dalam mengkomodir kebutuhan orang tua dan siswa serta dapat membantu guru dalah hal penilaian harian dikarenakan nilai bisa secara langsung masuk dalam berkas Google forms. 
Selain variasi tugas yang berbeda antara pembelajaran tatap muka dengan pembelajaran daring, aktivitas pembelajaran yang dilakukan pada masa pandemi corona ini tentu juga berbeda. Aktivitas pembelajaran juga lebih banyak dilakukan secara online. Hasil penelitian terdahulu yang dilakukan oleh (Nahdi et al., 2020) menunjukkan bahwa aktivitas pembelajaran yang banyak dilakukan pada masa pandemi corona di tingkat PAUD yaitu penugasan, Home Visit, laporan kegiatan harian anak. Proses penugasan dilaksanakan dengan memberikan tugas kepada anak-anak berupa Lembar Kerja anak. Home Visit dilakukan untuk mengetahui proses aktivitas pembelajaran anak ketika berada di rumah. Sedangkan laporan kegiatan harian anak dilakukan oleh orang tua masing-masing anak.

Berdasarkan latar belakang tersebut, tujuan penelitian ini adalah mengidentifikasi variasi tugas yang diberikan guru SD pada masa pandemi corona dan mengidentifikasi aktivitas pembelajaran yang diberikan oleh guru pada masa pandemi corona.

\section{METODE PENELITIAN}

Jenis penelitian ini adalah deskriptif kualitatif. Deskriptif kualitatif dalam penelitian ini digunakan untuk menghasilkan data deskripsi berupa variasi tugas dan aktivitas pembelajaran di Sekolah Dasar selama masa pandemi corona. Adapun data dalam penelitian ini adalah bentuk-bentuk tugas dan aktivitas pembelajaran di Sekolah Dasar pada masa pandemi corona. Sumber data berasal dari guru-guru SD di wilayah Boyolali sejumlah 20 orang. Pengumpulan data pada penelitian ini menggunakan kuesioner dalam bentuk Google Forms. Guru-guru SD diminta mengisi form sesuai dengan apa yang telah diterapkannya selama masa pandemi corona. Analisis data dalam penelitian ini menggunakan metode interaktif.

Analisis data dengan model interaktif dilakukan melalui tiga tahap yaitu: reduksi data, sajian data, dan penarikan simpulan. Reduksi data dilakukan dengan cara menyeleksi data yang bersumber dari variasi tugas dan aktivitas pembelajaran di Sekolah Dasar pada masa pandemi corona. Adapun sajian data dalam penelitian ini berupa deskripsi temuan tentang bentuk-bentuk tugas yang diberikan guru SD pada masa pandemi corona dan aktivitas pembelajaran di Sekolah Dasar pada masa pandemi corona. Lebih lanjut data tersebut disajikan dalam bentuk deskripsi data yang kemudian dianalisis dan dikaji didasarkan pada teori yang mendasari. Penarikan simpulan terkait dengan variasi tugas dan aktivitas pembelajaran di Sekolah Dasar pada masa pandemic corona dilakukan setelah melalui reduksi data hasil temuan.

\section{HASIL DAN PEMBAHASAN}

Hasil dan pembahasan penelitian ini fokus pada variasi atau bentuk-bentuk tugas di Sekolah Dasar pada masa pandemi corona dan aktivitas pembelajaran di Sekolah Dasar pada masa pandemi corona. Berikut ini hasil dan pembahasannya:

\section{Variasi Tugas di Sekolah Dasar pada Masa Pandemi Corona}

Variasi tugas berkaitan dengan jenisjenis tugas atau bentuk-bentuk tugas yang diberikan guru dalam proses pembelajaran. Berdasarkan hasil survei pada masa pandemi corona ini, guru-guru SD di wilayah Boyolali memberikan tugas pada muridnya dalam bentuk portofolio, praktik, demonstrasi, membaca materi di buku, dan soal latihan. Adapun soal latihan yang diberikan guru lebih banyak dalam bentuk pilihan ganda dan uraian.

Tugas yang diberikan guru juga bermacam-macam bentuknya, seperti tugas membuat kolase tentang corona, poster tentang corona, membuat video atau kolase mencuci tangan dengan benar, pemberian soal yang masih berkaitan dengan corona, membuat video hafalan tahfid, membuat video hafalan surat-surat pendek, dan 
mengirimkan foto yang berisi tugas. Aplikasi atau media penunjang pembelajaran yang digunakan guru-guru SD dalam memberikan tugas lebih banyak menggunakan aplikasi Whatsapp dan Google Forms. Hal ini sejalan dengan yang diungkapkan (Dewi, 2020) bahwa dalam hal pelaksanaan belajar di rumah bagi siswa Sekolah Dasar, guru meminta bantuan orang tua atau anggota keluarga siswa sebagai narasumber yang langkah-langkahnya sudah dibagikan melalui grup Whatsapp. Untuk laporan pelaksaan belajar di rumah dapat berupa foto atau video yang harus dikirim melalui grup kelas.

Seperti yang diungkapkan oleh salah seorang guru SD yang mengajar di daerah Karangduren. Ia mengungkapkan jika bentuk tugas yang diberikan berupa tugas praktik dan tugas mengerjakan soal latihan. Penjelasan materinya pun dilakukan dengan cara mengunduh materi dari internet kemudian dibagikan kepada siswa melalui aplikasi Whatsapp atau Google Forms. Adapun tugas-tugas yang diberikan yaitu meminta siswa mendokumentasikan tata cara mencuci tangan yang benar dalam bentuk video atau foto. Hal yang sama juga dilakukan oleh guru SD dari daerah Banyudono. Bentuk-bentuk tugas yang diberikan seperti portofolio, praktik, demonstrasi, serta soal latihan berupa pilihan ganda dan uraian. Tugas yang diberikan guru yaitu membuat video atau poster tentang corona, membuat kerajinan, membuat kolase urutan mencuci tangan yang benar, foto pekerjaan siswa baik dari buku maupun dari Google Forms. Pemberian tugas yang sama pun juga dilakukan oleh beberapa guru yang wilayah mengajarnya di daerah Banyudono.

Beberapa guru yang mengajar di daerah Babadan Kecamatan Sambi juga memberikan tugas berupa portofolio dan soal latihan yang terdiri dari pilihan ganda dan uraian singkat. Tugas portofolio mengharuskan siswanya membuat poster tentang corona yang berisi himbauan untuk rajin memcuci tangan dan tindakan pencegahan penularan corona. Tugas yang telah dilakukan atau dikerjakan siswa kemudian dikirim melalui aplikasi Whatsapp.

Guru dari daerah Boyolali lainnya pun juga memberikan tugas dengan meminta siswanya untuk mengerjakan latihan soal, praktik, dan demonstrasi melalui media aplikasi Whatsapp, Google Forms atau aplikasi Quizizz. Tugas yang diberikan juga disesuaikan dengan tema perharinya.

\section{Aktivitas Pembelajaran di Sekolah Dasar pada Masa Pandemi Corona}

Aktivitas pembelajaran berkaitan dengan bentuk-bentuk proses belajar mengajar yang dilaksanakan oleh guru selama masa pandemi corona. Berdasarkan hasil survei, guru-guru SD di wilayah Boyolali pada masa pandemi corona ini tentu saja menerapkan pembelajaran daring. Pembelajaran daring merupakan pola pembelajaran pilihan guru untuk merencanakan proses belajar yang sesuai dan efisien guna mencapai tujuan pembelajaran dengan memanfaatkan jaringan internet (Yanti et al., 2020). Adapun aktivitas pembelajaran di Sekolah Dasar selama masa pandemi corona yakni pemberian materi pembelajaran bersumber dari Youtube, diskusi tanya jawab melalui Whatsapp, pemberian materi dan soal melalui Whatsapp, dan meminta siswa untuk mengerjakan Lembar Kerja Siswa (LKS). Hal ini menunjukkan bahwa aktivitas pembelajaran di Sekolah Dasar selama masa pandemi corona lebih banyak dilakukan melalui aplikasi Whatsapp. Pemberian materi berupa video pembelajaran, materi pelajaran yang akan diajarkan, pengumpulan tugas, diskusi tanya jawab, semuanya dilakukan di grup Whatsapp.

Seperti yang diungkapkan oleh salah seorang guru yang mengajar di daerah Babadan Kecamatan Sambi bahwa aktivitas pembelajaran lebih banyak dilakukan di grup Whatsapp dengan cara, guru mengirimkan materi pembelajaran yang bersumber dari Youtube atau video yang dibuat oleh guru itu sendiri. Hal yang sama juga dilakukan oleh 
guru yang mengajar di daerah Simo Boyolali. Ia mengungkapkan jika aktivitas pembelajaran lebih banyak berupa diskusi tanya jawab di grup Whatsapp.

Namun, aktivitas pembelajaran yang lebih banyak dilakukan di aplikasi Whatsapp ternyata tidak selalu berjalan mulus. Berdasarkan hasil survei pada 20 guru SD di wilayah Boyolali, banyak guru yang mengungkapkan jika ada saja siswanya yang tidak mengumpulkan tugas dengan adanya pembelajaran daring ini. Seperti yang diungkapkan oleh guru SD yang mengajar di daerah Banyudono Boyolali. Ia mengungkapkan jika tidak semua siswa mengumpulkan tugas. Alasan siswa tidak mengumpulkan tugas pun bermacam-macam, yakni orang tua yang tidak memiliki handphone android, orang tua yang kurang perhatian dengan anaknya, keterbatasan kuota internet sampai dengan sinyal yang kurang mendukung. Orang tua yang sibuk bekerja sehingga tidak bisa mendampingi anaknya ketika belajar pun juga menjadi alasan mengapa terdapat siswa yang tidak mengumpulkan tugas sekolah.

\section{SIMPULAN}

Berdasarkan hasil dan pembahasan yang telah disajikan di atas dapat disimpulkan bahwa variasi tugas yang diberikan guru SD pada masa pandemi corona secara umum dalam bentuk portofolio, praktik, dan soal latihan. Adapun soal latihan yang diberikan berupa pilihan ganda dan uraian. Aplikasi atau media yang digunakan guru SD dalam memberikan tugas pada masa pandemi corona ialah Whatsapp. Selain aplikasi Whatsapp, guru juga menggunakan Google Forms dalam memberikan tugas. Kemudian, aktivitas pembelajaran di SD pada masa pandemi corona lebih banyak dalam hal pemberian video pembelajaran dari Youtube, diskusi tanya jawab melalui aplikasi Whatsapp, dan yang terakhir yaitu siswa diminta mengerjakan soal latihan yang ada di LKS ataupun soal yang dibuat oleh guru itu sendiri. Kedepannya, apabila pandemi corona masih berlangsung lama, pembelajaran berbasis e-learning seperti menggunakan aplikasi Zoom atau Google Meet perlu diterapkan oleh guru agar pembelajaran tidak terkesan monoton. Hal tersebut perlu dilakukan agar terdapat interaksi antara guru dam murid dalam pembelajaran daring.

\section{DAFTAR RUJUKAN}

Dewi, W. A. F. (2020). Dampak Covid-19 Terhadap Implementasi Pembelajaran Daring Di Sekolah Dasar. Edukatif: Jurnal Ilmu Pendidikan, 2(1), 55-61. https://doi.org/https://doi.org/10.31004 ledukatif.v2i1.89

Endriani, N., \& Syukur, Y. (2015). Kesiapan Siswa dalam MenyelesaikanTugas Sekolah. Konselor, 4(4), 185-190. https://doi.org/10.24036/02015436465 $\underline{-0-00}$

Nahdi, K., Ramdhani, S., Yuliatin, R. R., \& Hadi, Y. A. (2020). Implementasi Pembelajaran pada Masa Lockdown bagi Lembaga PAUD di Kabupaten Lombok Timur. Jurnal Obsesi : Jurnal Pendidikan Anak Usia Dini, 5(1), 177186.

https://doi.org/10.31004/obsesi.v5i1.52 $\underline{9}$

Pakpahan, R., \& Fitriani, Y. (2020). Analisa Pemanfaatan Teknologi Informasi dalam Pembelajaran Jarak Jauh di Tengah Pandemi Virus Corona Covid19. Journal of Information System, Applied, Management, Accounting and Research, 4(2), 30-36.

Pratiwi, E. W. (2020). Dampak Covid-19 Terhadap Kegiatan Pembelajaran Online Di Perguruan Tinggi Kristen Di Indonesia. Perspektif Ilmu Pendidikan, 34(1), 1-8. https://doi.org/10.21009/pip.341.1

Syarifudin, A. S. (2020). Impelementasi Pembelajaran Daring Untuk Meningkatkan Mutu Pendidikan Sebagai Dampak Diterapkannya Social Distancing. Jurnal Pendidikan Bahasa Dan Sastra Indonesia Metalingua, 
98 JURNAL PENDIDIKAN EDUTAMA, Vol.8, No.1 Januari 2021

$5(1)$,

$31-34$.

https://doi.org/10.21107/metalingua.v5 $\underline{\mathrm{i} 1.7072}$

Yanti, M. T., Kuntarto, E., \& Kurniawan, A. R. (2020). Pemanfaatan Portal Rumah Belajar Kemendikbud Sebagai Model Pembelajaran Daring Di Sekolah Dasar. Adi Widya Jurnal Pendidikan Dasar, 5(1), 61-68. https://doi.org/10.1017/CBO97811074 $\underline{15324.004 .}$. 